\title{
Exploring Samaritanism-New Insights and Fresh Approaches
}

\author{
Reinhard Pummer (D)
}

Citation: Pummer, Reinhard. 2021 Exploring Samaritanism - New Insights and Fresh Approaches. Religions 12: 769. https://doi.org/ 10.3390/rel12090769

Received: 19 August 2021

Accepted: 23 August 2021

Published: 15 September 2021

Publisher's Note: MDPI stays neutral with regard to jurisdictional claims in published maps and institutional affiliations.

Copyright: (C) 2021 by the author. Licensee MDPI, Basel, Switzerland. This article is an open access article distributed under the terms and conditions of the Creative Commons Attribution (CC BY) license (https:// creativecommons.org/licenses/by/ $4.0 /)$.
Department of Classics and Religious Studies, University of Ottawa, Ottawa, ON K1N 6N5, Canada; reinhard.pummer@uottawa.ca

"The Discovery of Samaritan Religion" was the title of an article published in 1972 by one of the leading scholars of Samaritanism in the twentieth century, John Macdonald of the University of Glasgow. At first glance, it may appear that the author wants to say that there was a time when the Samaritan religion had disappeared from the scholarly horizon. But what he actually means was that the "discovery of the true nature of Samaritan religion is a very modern happening"1 ${ }^{\prime 1}$ Knowledge about the Samaritans among Jews and Christians was never lost, neither in the Middle East nor in Europe, where the New Testament story of the Good Samaritan is particularly well known. What changed over the course of centuries, and particularly in recent decades, is the understanding of Samaritan beliefs on the basis of their own traditions, as found in their writings and oral traditions. Both early Christian and rabbinic sources had preconceived notions of the Samaritans' beliefs and practices. Influenced by the biblical passage 2 Kings 17:24-42, many tended to see the Samaritans as a Jewish sect that strayed from the true path of the Yahwistic religion of Israel and practiced a syncretistic form of faith. But even if the Samaritans were no longer accused of syncretism, they were still considered a sect of Judaism. ${ }^{2}$ However, this view was eventually abandoned because scholarship gained a more nuanced understanding due to having better access to the Samaritans' own literature, to new archaeological discoveries such as the Dead Sea Scrolls and the excavations of Samaritan synagogues, and, above all, of the temenos of what once was the Samaritan sanctuary on Mt. Gerizim.

\section{Samaritan Studies: Prehistory-Early History-Contemporary History}

The first European scholar to include the Samaritans in his research was Guillaume Postel (1510-1581). ${ }^{3}$ In his Linguarum duodecim characteribus differentium alphabetum, introductio (An Introduction to the Alphabetic Characters of Twelve Different Languages), published in 1538 (Postel 1538), he reproduced and discussed the Samaritan alphabet, and on a voyage to Constantinople, he acquired a grammar written in Samaritan characters but in the Arabic language, the first Samaritan manuscript to enter Europe. In 1549-50, on a second voyage to the Orient, he made a point to visit the Samaritans; they showed him a copy of the Torah in the Samaritan script. In Damascus, the Samaritans made a copy of their Arabic Pentateuch for him. Although he notes that they have other chronicles and prophetic writings of a fantastic and ridiculous nature, he characterizes them as practicing an irreproachable cult, absolutely without any traces of the ancient idolatry. ${ }^{4}$

The first time a Samaritan text appeared in an occidental work was in 1598 when Joseph Justus Scaliger (1540-1609) issued his second edition of his Opus de emendatione temporum (Study on the Improvement of Time (viz. Chronology)) in which he included the Samaritan Book of Joshua and two Samaritan calendars. ${ }^{6}$ He translated and commented on the calendar and dealt with other subjects, refuting among others what the Jewish traveller Benjamin of Tudela (1130-1173) said about them. In his Itinerary, Benjamin claimed that the Samaritan alphabet lacks three letters, $\pi, \pi$, and $y$, which the Samaritans replace with $\kappa$, which in turn proves that they are not descended from Israel because they cannot read the whole law of Moses. ${ }^{7}$ Scaliger calls this a Jewish calumny and insists that they read every word like the Jews. They also did not falsify the script like the Jews but preserved the 
pure Mosaic characters, as had already been proven by Postel. Moreover, Scaliger underlines that they once mixed idolatry with the worship of God, as stated in 2 Kings 17:29-32, but now they have such an aversion against any idolatry that they seem to surpass the Jews in this regard. ${ }^{8}$ Another avenue was opened by Scaliger, viz. the correspondence between European scholars and the Samaritans. He sent two letters in Hebrew to Nablus and Cairo, asking the Samaritans not only for details of their religious practices, but also for copies of the Pentateuch, the Hebrew Book of Joshua, and a collection of their hymns. However, he never saw the responses because he died before they arrived. This was the beginning of the correspondence that was carried on by European scholars until the early twentieth century. ${ }^{9}$ The final stage in the beginnings of Samaritan studies in Europe - their Prehistory, as it were - was the edition of the Samaritan Pentateuch and the Samaritan Targum by Jean Morin (1591-1659) in volume 6 of the Paris Polyglot that was published by Guy Michel Le Jay in $1645 .{ }^{10}$ Copies of both works had been acquired by Pietro della Valle (1586-1652) in Damascus in 1616. Of course, other authors also became aware of Samaritan writings in the seventeenth and eighteenth centuries, as becomes clear from the numerous works that refer to Samaritan subjects. To highlight only one publication from the eighteenth century, John Mawer's Roma meretrix, published in 1737 (Mawer 1737), the title-too long to quote here in its entirety-contained the following announcement: "With a prefatory discourse, address'd to His Grace, the Lord Archbishop of Canterbury, Wherein is occasionally asserted The Usefulness and Antiquity of the Samaritan Pentateuch, which with the Samaritan Version is intended to accompany the Hebrew Text, with the Greek and Ethiopic Versions, \&c. in a New Edition of the Original Scriptures, whereof a large Specimen is prepared for the Press". In the Dedication, he notes, among others, that the "Learned, in general, seem to have no just Notion" of the Samaritan Pentateuch. Following in part Josephus' story about Manasse-without saying so-he believes that the Samaritan Pentateuch was the Pentateuch that Manasse, the brother of the Jerusalem high priest Jaddua, took with him when he built the temple on Mt. Gerizim (cf. Ant. 11:302-325). Mawer further underlines that the Samaritans preserved it ever since because they always, without interruption, had a succession of Aaronite priests to this day.

To continue with the above terminology, the nineteenth (and early twentieth) century can be called the Early History of Samaritan studies. A number of scholars visited the Samaritan community in Nablus to study their religion firsthand, and in many instances, the foundations for later studies were laid in this time. The number of publications on Samaritan topics rose significantly. Among the most important scholars who contributed to these foundations are the following (listed in alphabetical order): Adolf Brüll, Charles Simon Clermont-Ganneau, Arthur E. Cowley, Moses Gaster, Abraham Geiger, Wilhelm Gesenius, Abraham Elijah (Albert) Harkavy, Moritz Heidenheim, Samuel Kohn, Adalbert Merx, Adolf Neubauer, Julius Petermann, and Antoine-Isaac Silvestre de Sacy. ${ }^{11}$ Some of their works, such as the collection and edition of the Samaritan liturgy by Arthur E. Cowley ${ }^{12}$ or the edition of the Arabic Book of Joshua by Th. Guil. Joh. Juynboll, ${ }^{13}$ to name only two examples, have not yet been replaced with more recent editions. Of course, there were also voices that, on the one hand, welcomed the availability of new primary sources, but on the other hand pointed out that for the history of the Samaritans they are of inferior quality to the writings of ancient ecclesiastical and secular historians. Moreover, it was claimed that all the Samaritan sources date from the time when the Samaritans had reached the end of their history, which came with the beginning of Christianity and the fall of Jerusalem. It was said that when Jerusalem fell, the Samaritans lost their standing in the world. Nevertheless, it was admitted that the primary sources are to be used to enrich the more reliable historical sources from outside the Samaritan community. Such were the views presented in the mid-nineteenth century by Joseph Grimm (1827-1896) in his book of 1854 Die Samariter und ihre Stellung in der Weltgeschichte. ${ }^{14}$ Twice, once at the end of his Introduction and once at the very end of his book, he makes the prediction, wellknown from other authors-older ${ }^{15}$ and newer ${ }^{16}$ - that the Samaritans are doomed. In very drastic colors, he described the image which, in his opinion, they presented in his time: 
"ein Bild gewaltsamer Todeszuckungen, ohnmächtiger Reaction der letzten Lebensreste, die heut zu Tage übergegangen ist in den Todesschlummer schmerzloser Betäubtheit!". ${ }^{17}$ And finally: "So vegitieren die Samariter ihrem endlichen Erlöschen entgegen". ${ }^{18}$

We now proceed to the Contemporary History. Building on the foundations laid in the earlier period and expanding the horizon with new discoveries and methods, in the twentieth and twenty-first centuries, great strides were made in the exploration of all aspects of Samaritan history and traditions. Scholars have not only focused on the Samaritan Torah, Targum, and the Samaritan Book of Joshua, but they have also studied Samaritan liturgical, historical, grammatical, lexical, legal, midrashic, and other texts from different ages under different viewpoints such as history, linguistics, theology, and others. A number of the texts were edited and/or translated, and others are in preparation. They range from editions of the Samaritan Pentateuch to a new edition and English translation of the midrashic work Tibåt Mårqe and to a translation of classical Samaritan poetry of the fourth century, to name only a few of the most recent works. ${ }^{19}$ A major contribution is the edition and English translation of the important chronicle Kitāb al-Tarīkh of Abu ' 'l-Fath. ${ }^{20}$ Moreover, spectacular discoveries of various caches of manuscripts, such as the finds in the Abū Shinjeh cave in the Wadi Daliyeh, ${ }^{21}$ north of Jericho and the Dead Sea area, ${ }^{22}$ have brought to light texts that have put Samaritan studies on a new footing. The second major contribution to our knowledge of the Samaritan tradition was made by archaeology. The archaeological discoveries range from inscriptions to synagogues and, above all, the temenos of the Samaritan temple on the main peak of Mt. Gerizim, together with the remains of the city surrounding the temple before its destruction in the second century BCE. It is in large part thanks to archaeology that we can appraise anew Flavius Josephus' account of the Samaritans. ${ }^{23}$ Another field of research that recently has begun to play an important role in Samaritan studies is the renewed analysis of the books of Kings, Ezra-Nehemiah, Chronicles, and others. This has led to new and more nuanced insights into the relations between the northern and southern Yahwists in biblical times. And finally, the newest addition to the methods applied to Samaritan studies is that of the social-scientific approach (social and cultural anthropology) to the study of the contemporary Samaritan society; beginning in the late twentieth and the early twenty-first century, a number of articles, monographs, and doctoral theses in this field have already been authored. ${ }^{24}$

To advance the study of the various aspects of the Samaritan tradition further, in the mid-1980s the Société d'Études Samaritaines (SES), was founded in Paris. It organizes regular meetings of scholars to discuss new developments in the field. The first official congress of the SES took place in 1988 in Tel-Aviv. It was preceded by an international Table Ronde in Paris in 1985 that was organized around the theme "Les manuscrits samaritains. Problèmes et méthodes". Proceedings were published for this Table Ronde as well as for all congresses of the SES. So far, nine congresses have been held. The tenth congress was planned for 2020, but due to the COVID-19 pandemic, it had to be rescheduled and is now due to take place in Budapest, Hungary, from 21-26 July 2022. (www.socsam.org; Appendix A). ${ }^{25}$

\section{Unsolved Issues and Research in Progress}

Despite the remarkable progress of the field in recent decades, much remains to be accomplished. In addition to the need for more editions and more translations of Samaritan works into European languages, major questions are still unanswered and subject to debate: When did the Samaritans as a separate Yahwistic community originate? When did tensions between Samri(t)ans and Judeans first become identifiable in the Bible? Was it all of Judah that came to regard the temple on Mt. Gerizim as being in illegitimate competition with the temple in Jerusalem? What role did northern and southern Yahwists play in the formation of the Pentateuch? The new search for answers to these questions in light of the changed approaches to the biblical texts has brought about a closer relationship between Samaritan studies and biblical studies, two fields which in the past went largely their own ways. 
The issue of the time when Samaritans and Judeans separated has not yet found a clear-cut answer. ${ }^{26}$ It is closely linked with the question as to when tensions between the two communities began. It appears now that they did not go back to the Persian period (539-332 BCE) when each community lived in its separate province. Rather, the first signs of tension appeared in the late fourth or in the early third century BCE when both lived in the united province and had "to compete for the favor of the Ptolemaic and Seleucid potentates". ${ }^{27}$ But it was in the Hellenistic period when the conflicts came to the fore, as a critical reading of Ezra-Nehemiah, Chronicles, and 2 Kings 17 shows. Still, even in the late second century BCE, when the Hasmonean ethnarch and high priest John Hyrcanus I (134-104 BCE) destroyed the temple on Mt. Gerizim, there was no final break or "schism", as some scholars once called it. ${ }^{28}$ In the first century CE, Flavius Josephus depicted the Samaritans in a negative light to contrast them with the Jews, whom he wanted to be looked at sympathetically by the Romans. ${ }^{29}$ But even then no iron curtain had gone down between the two branches of Yahwism. ${ }^{30}$ Gradually, the two branches developed their own views of Scripture $^{31}$ and their own liturgical, legal, linguistic, and historical traditions that set them apart from the respective Other.

Another area that has been discussed anew is the matter of the Samaritan Pentateuch. The past assumption that the Samaritans took over the Judean Pentateuch and made a number of modifications is no longer accepted. But even the newer hypothesis that the Pentateuch, compiled in Jerusalem, was from the beginning intended for both Yahwists in Judea and Yahwists in Samaria, and that, to accommodate the Samarians, a number of concessions were made, such as the accounts of the Shechem covenant tradition in Deuteronomy and in Joshua, is now questioned by scholars. Recent Pentateuchal research has shown that the North was involved in the creation of the Pentateuch early on. Thus, it is no longer believed that the Samaritans simply made redactional changes in "a more or less predominantly Judean text". ${ }^{32}$ Rather, the Pentateuch is seen as a heritage that is common to Samaritans and Jews and dates from the time before the relationship between the two Yahwistic communities began to deteriorate. ${ }^{33}$ It was probably completed in the second half of the Persian period. ${ }^{34}$ What we do not know is how much time elapsed before the additions were made that brought about the distinctive Samaritan Pentateuch. ${ }^{35}$

A special question is: what was the status of the temple on Mt. Gerizim in the Pentateuch, especially in light of the cult centralization law (Deut. 12:4-7, 11-12, 13-14, 26-27)?. ${ }^{36}$ Without going into details here, some points are named. First of all, the Gerizim temple is not mentioned as such in the Pentateuch or, for that matter, in any other book of the Hebrew Bible. Only indirect or coded references to the Gerizim temple have been identified in recent research. ${ }^{37}$ Harking back to a thesis first proposed in 1934 by Albrecht Alt, ${ }^{38}$ Heckl believes that it is possible that the construction of the two parallel temples in Jerusalem and on Mt. Gerizim was agreed upon by both northern and southern Yahwists and perhaps mutually supported. ${ }^{39}$ Although these two temples probably were not the only Yhwh temples in Palestine, ${ }^{40}$ they were the most important ones. Further research will have to take these new hypotheses into account.

\section{Exploring Samaritanism - From Antiquity to Today}

The contributions to this Special Issue on Samaritanism address salient points in the ongoing debate. They range from issues concerning the origin of the Samaritans, the Samaritan Pentateuch, the temple on Mt. Gerizim, and the New Testament to the present situation of the Samaritans in Palestine. They are discussed here in chronological order, beginning with the problem of the origins of the Samaritans and ending with their contemporary situation.

The vexed question of the origin of the Samaritans is the topic of Magnar Kartveit's article "Theories of the Origin of the Samaritans - Then and Now". His aim in this contribution is not to discuss the origin of the Samaritans as such but rather to give an overview of the different scholarly opinions on this issue. Thus, he presents the Samaritans' own 
version and that of Flavius Josephus, considers whether it can be hypothesized that they come from the city of Samaria, and discusses the contributions made by the discoveries of the Qumran scrolls and the inscriptions found during the excavations on Mt. Gerizim and on the island of Delos. He concludes that a combination of continuity and estrangement dominates the scholarly field on the question of the origin of the Samaritans today and foresees that this will remain the case for the time being.

The relationship between the Samaritan Pentateuch and the Jewish versions of the Pentateuch is the subject of the chapter "The Samaritan and Jewish Versions of the Pentateuch: A Survey" by Ingrid Hjelm. The author describes the nature of the Samaritan Pentateuch as seen by earlier as well as by contemporary scholars, gives an overview of its distinctive contents, and discusses the various editions of it. Her discussions range from the characteristics of and the major variants in the Samaritan Pentateuch to the question of the right cult place according to the Samaritan view. A special section is devoted to the editions and translations of the Samaritan Pentateuch - from the Abisha Scroll (whose date of origin is disputed) to the first English translation, which was published in 2013.

In Bell. 1.63, Josephus claims that the Gerizim temple was "modelled on that at Jerusalem", and in Ant. 11.310. he has the satrap of Samaria, Sanballat, promise Manasseh, the brother of the high priest in Jerusalem, to build for him a temple on Mt. Gerizim similar to the one in Jerusalem. Furthermore, the excavator of Mt. Gerizim, Itzhak Magen, writes: "We may conclude that the first-phase temple at Mt. Gerizim was modelled on the Second Temple in Jerusalem that was built by Zerubbabel during the Return to Zion period (Ezra 1:2-6; Chronicles 36:23)" ${ }^{41}$ However, according to Magen, "in the second phase, in the Hellenistic period, an independent Samaritan tradition developed that, although influenced by the temple in Jerusalem, no longer exactly imitated it". ${ }^{42}$ Anne Katrine de Hemmer Gudme in her article, "Was the Temple on Mount Gerizim Modelled after the Jerusalem Temple?", points out that, if that were so, it would strengthen the argument that the Gerizim cult was derived from the cult in Jerusalem. Since Magen draws his comparison mainly from the temple described in the Book of Ezekiel (40:1-42:20; 43:1-5, 13-27; 44:1-9; 46:1-12), she confronts the evidence of the finds on Mt. Gerizim with the texts in Ezekiel. Apart from the fact that Ezekiel's temple hardly is a dependable reflection of the Jerusalem temple in the Persian period, she also underlines that the Mt. Gerizim finds from that period are insufficient to conclude that they show a similarity with the Jerusalem temple.

Benedikt Hensel presents what the title of his article announces, viz. new insights into the early history of Samari(t)an-Jewish relations. Focusing on Ezra 4:1-5 and 6-23 as pars pro toto, as it were, he argues that Ezra-Nehemiah and Chronicles contain the first signs of anti-Samaritan polemics in the Bible. In a correction of what he proposed in his book, Juda und Samaria, he now dates the beginning of this confrontation in the late fourth to early third century BCE as opposed to the late second/early first century BCE in his earlier work. In the course of Judaism's self-discovery, its differences from the Samarians were emphasized in a process that he calls "literary othering". Ezra-Nehemiah seeks to underline that the postexilic community, as opposed to the Samarians, is continuous with the earlier monarchic period religiously, politically, and genealogically. Similarly, Chronicles also underlines the continuity with the kingdom of Israel in contrast to the religious and political discontinuity of the Samarians. In addition, it insists on the Jerusalem-exclusive interpretation of the Pentateuch, foreshadowing the eventual division into the Samaritan Pentateuch and the Masoretic text. Hensel believes that such literary polemics did not mirror the lived reality since the material culture, as far as it is known, does not indicate that the two communities in the Persian and Hellenistic periods drifted apart. But eventually, i.e., in the second/first century BCE, the literary dispute led to the separation of Judeans and Samarians - they became "Jews" and "Samaritans", each with their own traditions and practices.

Around 1962, an important find was made in the cave Mughâret Abū Shinjeh in Wadi Daliyeh, a valley $14 \mathrm{~km}$ north of Jericho. It included bones of about 200 people, fragments of manuscripts, coins, and bullae. Jan Dušek presents a succinct discussion of the impor- 
tance of this find in his article, "The Importance of the Wadi Daliyeh Manuscripts for the History of Samaria and the Samaritans". It is likely that these manuscripts were brought into the cave by inhabitants of the city of Samaria after the murder of Alexander's governor of Syria, Andromachus, in ca. 332 BCE. Most of the documents were written between 375 and 332 BCE, i.e., in the late Persian period, and witnessed by governors, judges, and prefects. Most of the witnesses had Yahwistic names. On the basis of the data gleaned from the Wadi Daliyeh finds, Dušek dates the foundation of the Yhwh sanctuary on Mt. Gerizim to about the time between 424 and 407 BCE. Furthermore, he sees the Pentateuch as a new document that was produced in the fourth century BCE, uniting the Yahwists in Judah and in Samaria under the same Law and guaranteeing the coexistence of the two sanctuaries on Mt. Gerizim and in Jerusalem. However, we cannot know whether this was already the Pentateuch known from later times. The fact that among the Wadi Daliyeh documents no religious texts were found -in contrast to the manuscripts found by the Dead Sea-leads Dušek to hypothesize that in the fourth century BCE the Pentateuch was not yet considered a precious religious object to be taken along by refugees in the flight before their persecutors. A confirmation for this assumption lies, in his opinion, in the absence of any discovery of biblical texts from the Persian period.

While it is-or at least was-commonly assumed that the Hasmonean period was the time in which Samaritans and Jews parted ways, Jonathan Bourgel cautions against categorical statements to this effect in his contribution "The Samaritans During the Hasmonean Period: The Affirmation of a Discrete Identity?". Beginning with a discussion of the situation of the Samaritans on the eve of the Hasmonean revolt and at its outbreak, he then details their fate during Hasmonean rule. Bourgel believes that the destruction of the Mt. Gerizim temple and the surrounding city by John Hyrcanus in 111-110 BCE may not have been an act of exclusion-John Hyrcanus may well have seen the Samaritans as true Israelites - but the Hasmonean's forceful attempt to integrate the Samaritans into the Judean state, avert them from the Mt. Gerizim priesthood, and redirect their offerings to the Jerusalem temple in which he was high priest. He then discusses the production of the Samaritan Pentateuch since it is often dated to the Hasmonean period and since some scholars believe that it contributed to the split between the two Yhwh-worshipping communities. However, the validity of the arguments in favour of such an assumption are all questioned by Bourgel. Equally questionable, according to Bourgel, is the reading of anti-Samaritan polemics into certain Jewish writings of the second century BCE. There probably were some, but this must not be exaggerated because it is not possible to be sure whether the Samaritans are intended or not. With other scholars, Bourgel also questions the accuracy of the hypothesis that the use of miqva' ot was forced on the Samaritans by John Hyrcanus after he had destroyed their temple. All things considered, the relationship between the Samaritans and the Hasmoneans was not simply one of hatred and repudiation. Nevertheless, in the end, the consequences of the treatment of the Samaritans by the Hasmoneans did lead to a division between Samaritans and Jews, even though this does not mean that all contacts were broken at that time.

In his contribution "The Ancient Samaritans and Greek Culture", Pieter W. van der Horst gathers the available evidence for the impact that Greek literature and practice had on the ancient Samaritans in Palestine and in the diaspora. He tries to distil as much as possible from the meagre evidence that has been preserved. To begin with, he points out that the request by (some?) Samaritans (or Sidonians) to rename the Mt. Gerizim sanctuary Temple of Zeus Olympios or Xenios described in 1 Maccabees 6:2 and Josephus, Ant. 12.257-264, is not so much evidence for Samaritan Hellenism as testimony to the influence of Hellenistic culture on "liberal" and "orthodox" Samaritans, just like on the Jews. Furthermore, the fragments of a poem by Theodotus (probably second century BCE), that praise Shechem as "a holy city", were, according to van der Horst, undoubtedly written by a Samaritan. Another example is a fragment of the work of the historian now called Pseudo-Eupolemos, also probably from the second century BCE. Although it contains nothing specifically Samaritan and, in fact, it is not known whether it derives 
from a Samaritan or Jewish author, it depicts Abraham as having been received in the temple of the Most High on Mt. Gerizim. In van der Horst's opinion, Pseudo-Eupolemos seems to have combined Gen. 12:7 and 14:18 and added that Abraham was received in the temple on Mt. Gerizim in an attempt to claim priority for the temple on Mt. Gerizim over the one in Jerusalem. The fragments of the so-called Samaritikon, possibly a Samaritan Greek version of the Pentateuch, as well as Greek inscriptions citing biblical texts in Greek, are evidence that the Samaritans used a Greek translation of the Bible, although probably not of their own making but an adapted version of the Septuagint. In addition, a number of Samaritan inscriptions in Greek have come to light in both Palestine and the diaspora, such as Delos (second century BCE), Thessalonica (fourth or fifth century CE), and Tyre (fifth or sixth century CE). The Delos inscriptions attest that the Samaritans had embraced Greek customs when they record the honoring of benefactors with crowns or wreaths and inscriptions. In the fifth century CE, the Samaritan apostate, Marinus of Neapolis, became head of the Athenian Neo-Platonic Academy. The existence of a crypto-Samaritan, Faustinus, in the Byzantine government service, as described by Procopius of Caesarea (sixth century), is testimony to a thorough acquaintance with the Greek language and customs by these Samaritans. For the Roman period, van der Horst assumes that the majority of the Samaritans possibly understood and spoke Greek, similar to the situation among the Jews.

Analysing the well-known New Testament passages dealing with Samaritans, Martina Böhm in her article, "Samaritans in the New Testament", underlines that in all cases the reference is to the Samaritans as a religious, not just geographical or political, community. For lack of evidence, we cannot know what the attitude of the historical Jesus towards the Samaritans was. Taking into account the recent results of a renewed understanding of the history of the two Yahwistic Israelite faiths in the Persian and Hellenistic periods, Böhm underlines that the Samaritans must have been more than an insignificant religious community in New Testament times. The term $\Sigma \alpha \mu \alpha \rho \tilde{i} \tau \alpha \iota$ in this sense is found in Matthew, John, and Luke-Acts, but Paul may also have had the Samaritans in the religious sense in mind even if during his time this term was not yet current. Rather, before 70 CE it was above all the term 'I $\sigma \rho \alpha \eta \lambda \tilde{i} \tau \alpha \iota$ that included the Samaritans. Especially in the early diaspora sources, the Samaritans were therefore, on the whole, undetectable. Such designa-

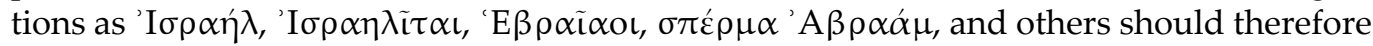
be closely examined so as to discern who is intended by them. Böhm then discusses in detail the classical Samaritan texts in the New Testament in view of their theological concept of the Samaritans. She concludes that all New Testament texts involving the Samaritans are anchored in historically accurate information about the Samaritans' religious outlook.

In the last few decades, Samaritan studies have experienced a veritable boom even though the number of specialists is still small in comparison to other fields. Among the latest contributions is a new edition and English translation of one of the most important Samaritan works, Tibåt Mårqe, a collection of interpretations (midrashim) of certain passages of the Pentateuch. Abraham Tal in his article, "Tibåt Mårqe: A New Edition with English Translation", introduces the latest edition of the work that is based on a manuscript that is older than any manuscript known previously. It was discovered by the Samaritan scholar Israel b. Gamaliel Tsedaqa in the National Library of Russia in St. Petersburg around the year 2000. Mårqe lived in the fourth century CE and used the Aramaic of the time for his compositions. On this basis, it was determined that of the six books that now constitute Tibåt Mårqe, only book one was authored by him. Called "The Book of Wonders", it is an amplified version of the story of the liberation from Egyptian slavery as recounted in the book of Exodus. The other books date from later periods. They are written in late Hebraized Aramaic and, some portions, in Neo-Samaritan Hebrew. They deal with various texts of the Pentateuch. Apart from the linguistic aspects of the work, Tal presents his new edition and translation with explanatory notes.

Indications of the possible existence of a Samaritan synagogue in Apollonia-Arsuf/ Sozousa, located on the coast of central Israel between Caesarea and Jaffa, are discussed by Oren Tal in his article, "A Samaritan Synagogue of the Byzantine Period at Apollonia- 
Arsuf/Sozousa?". As the question mark after the title indicates, the available archaeological evidence is very scanty. What was found in the 2014 season of excavations is a Samaritan mosaic inscription in Greek and Aramaic in Samaritan script. The Greek part includes the typically Samaritan phrase "Only One God". From the orientation of the relics of two walls and the mosaic floor towards Mt. Gerizim, Tal concludes that the building once was a Samaritan synagogue. He dates its construction tentatively to the fourth or fifth century $\mathrm{CE}$ and its destruction to the late Byzantine or early Islamic period.

The Samaritans in rabbinic literature have been the subject of many studies. Most focused on the Mishna, Tosefta, and the two Talmudim. As distinct from these works, Andreas Lehnardt in his article, "The Anti-Samaritan Attitudes as Reflected in Rabbinic Midrashim", investigates the subject in rabbinic biblical commentaries, the Midrashim, that go back to the Amoraic period, i.e., from the third to the fifth centuries CE. In particular, he analyses the passages in Midrash Genesis Rabbah, probably edited in the fifth century, that involve discussions with the eminent Rabbi Me'ir who lived in the second century. Lehnardt's primary interest does not lie in the question of whether the dialogues reported in this source are historical or not but what role the Samaritans played in the formation of the teachings of the rabbis. The analyses of these texts show that the Samaritans and their religious views in Bereshit Rabbah are not what interests the rabbis. Rather, it is the rabbis' self-definition that underlies the "dialogues". The fictitious Samaritans are shown to be inferior when it comes to the exegesis of the Torah. In their debates, some passages make use of pagan scientific and philosophical arguments to counter the Samaritan positions, i.e., arguments that are accessible to all humans. Thus, the "dialogues" were used by the rabbis to give their own identity a clearer image.

Although, like the Jews, the Samaritans are a branch of Israelite religion, they are the much smaller offshoot. As a consequence, traditions that are the same or similar in both religions are commonly explained as borrowings from the larger offshoot by the smaller. Steven Fine, however, proposes that, at least in the case investigated by him, the direction of the borrowing was the opposite-from the Samaritans to the Jews. In his article, "'They Remembered That They Had Seen it in a Jewish Midrash': How a Samaritan Tale Became a Legend of the Jews", he traces the path of a Samaritan legend from a medieval Samaritan chronicle through early modern rabbinic literature to nineteenth and early twentieth century Jewish scholarship. The story is known as the "Epistle of Joshua son of Nun" or the "Shobakh Legend". Versions of different lengths and detail are found in Samaritan medieval chronicles. The legend describes Joshua's heroic fight against and victory over the Armenians led by their king Shobakh. It was appended to Abraham ben Samuel Zacuto's Sefer Yuhasin (Book of Lineage (of Jewish sages and their teachings)) which was originally published in 1566 by the rabbi and scholar Samuel Sulam (Shullam). In his introduction to the legend of Shobakh, Sulam states that he found it in the Book of Chronicles of the Samaritans, although he adds the puzzling remark that "they remembered that they had seen it [the legend] in one midrash of the Jews". Unfortunately, it is not clear to whom "they" refers. Fine, however, identifies several themes in the legend that point to a Samaritan origin. Later, the story was included in Hebrew and Yiddish literature up to the nineteenth and twentieth century.

The present-day situation of the Samaritans as a small minority in a predominantly Muslim society is discussed in Julia Droeber's contribution "Avoidance as Inter-Religious Competence? Samaritans and Their Religious 'Others' in Nablus, Palestine". Nablus is inhabited by Muslims, Christians, and Samaritans. ${ }^{43}$ The aim of Droeber's article is to determine the inter-religious competence of the Samaritans in Nablus (Kiryat Luza) that allows them to live peacefully with the members of the other two religions in everyday life. (For various reasons, Samaritans in Holon were not included in her research for this project). By inter-religious competences, she means the skills that are needed to deal with situations in which different religions overlap, to understand what happens in such situations, and to become able to deal with them. To ascertain what skills Samaritans may have acquired in past encounters that may inform their present behaviour, she summarizes what is known 
of the history of interactions between Samaritans and members of other religions from the fourth century CE to the twenty-first century. Droeber surmises that the historical experiences contributed to the development of tactics that make coexistence possible. For the present, the living together is relatively peaceful which by a large measure is due to the avoidance of frictions and the emphasis by the Samaritans on theological, social, and political similarities with the majority group. However, this applies primarily to the public sphere. In private, a hidden transcript exists that expresses the negative feelings and attitudes towards the members of the other communities that cannot be expressed in public. But both the public and the private discourse have the maintenance of the peace as their aim. Finally, Droeber points out that politics plays a major role in determining the interreligious rapport in Nablus: "Representatives of all groups involved mention, in one form or another, that there is a 'common enemy' - Israeli occupation - that binds them together in a shared struggle. It is reason and proof of the 'brotherhood' of Samaritans, Christians, and Muslims in Nablus". Thus, the sense of local identity is reinforced by the present political context.

The contemporary Samaritans are also the subject of the article "From Religious to Cultural and Back Again: Tourism Development, Heritage Revitalization, and Religious Transnationalizations among the Samaritans" by Fanny Urien-Lefranc. The article describes and analyses the Samaritans' ongoing attempts to define their identity and to adapt it to the changing environments. The Samaritans are at the same time close to Judaism but different from it, and as citizens of Palestine and Israel they are special. To themselves and to the outside world they appear to be-and want to be seen as the guardians of an ancient tradition whose religion and culture are closely woven together. Tourism plays a large role in this process of renewed self-identification. Every year large numbers of tourists-Palestinians, Israelis, and foreigners-come to see the Passover sacrifice on Mt. Gerizim and to observe the ceremony that is said to go back to biblical times. By their presence, the spectators unwittingly legitimize the ritual as re-enacting the biblical ceremony. The Samaritans are seen by the media and the tourists as living witnesses to ancient biblical history. The site of Mt. Gerizim plays a major role in the identity of the Samaritans. At the same time, the Palestinian Authority chose it to defend the Palestinian identity by submitting in 2012 a request to the UNESCO to include the mountain and the Samaritans on the World Heritage List. As a reaction to this move, the Israeli State established an archaeological park on the top of the mountain also in 2012 and insisted on the Jewish character of it. As the then Israeli Minister of Protection and Environment said: the Israeli State "will not waive [its] right to commemorate the Jewish heritage and to facilitate accessibility to heritage sites". The Samaritans, as active participants in tourism, developed means through which they articulate and convey their image as keepers of an ancient heritage and members of the authentic and discrete "Samaritan Israelite" culture. Among these means are a choir that performs Samaritan religious songs at international cultural events and a cookbook with Samaritan recipes. In addition, they use the Internet to find ancient manuscripts, not to bring them home to Nablus, but to draw attention to them so that they can be accessed by non-Samaritans, who in turn can learn from them about the Samaritan heritage. The newest phenomenon is the transnationalization of Samaritanism in the sense that populations geographically far removed from Mt. Gerizim are attracted by the values and the expressions of self-identity of the Samaritans and want to become Samaritans, although not through formal conversion, which does not exist in Samaritanism, but through adherence to Samaritan beliefs and practices. Urien-Lefranc studied this phenomenon in Brazil, where she found that the Internet and social networks play an important role in it. The Samaritans in Palestine are of two minds in this matter. On the one hand, the Neo-Samaritans are looked at with curiosity and enthusiasm, but on the other hand, the Samaritans in Palestine ask themselves whether Samaritanism should be based on ethnicity or whether it can be adopted by choice. For the time being, these new Samaritans help to augment the visibility of Samaritans as an authentic and ancient tradition.

\section{Summary}


As is clear from the contributions to this Special Issue, Samaritan studies have made important progress in the late twentieth and early twenty-first centuries. New answers to age-old questions are being put forth, and the methods of new fields of study are used to explore the present situation of this religion whose members are living in a varied religious and political environment and are doing everything in their power to survive and adapt to the ever-changing world around them.

Funding: This research received no external funding.

Conflicts of Interest: The author declares no conflict of interest.

\section{Appendix A. Congresses and Proceedings of the Société d'Études Samaritaines}

Table Ronde in Paris in 1985

Rothschild, Jean-Pierre and Guy Dominique Sixdenier, eds. Études samaritaines. Pentateuque et Targum, exégèse et philologie, chroniques. Actes de la table ronde: "Les manuscrits samaritains. Problèmes et méthodes" (Paris, Institut de Recherche et d'Histoire des Textes, 7-9 octobre 1985). Collection de la Revue des Études Juives 6. Louvain-Paris: E. Peeters, 1988

(Although in effect being the first conference on Samaritanism, it was not counted as a congress.)

Congresses of the SES

(1) Tel Aviv, Israel: 11-13 April 1988

(2) Oxford, U.K.: 6-10 August 1990

(3) Paris, France: 12-16 July 1992

(4) Milan, Italy: 8-12 July 1996

(5) Helsinki, Finland: 1-4 August 2000

(6) Haifa, Israel: 5-8 July 2004

(7) Pápa, Hungary: 15-17 July 2008

(8) Erfurt, Germany: 15-20 July 2012

(9) Prague, Czech Republic: 31 July-5 August 2016

Proceedings

(1) Tal, Abraham and Moshe Florentin, eds. Proceedings of the First International Congress of the Société d'Études Samaritaines, Tel Aviv, April 11-13, 1988. Tel Aviv: Chaim Rosenberg School for Jewish Studies, Tel Aviv University, 1991

(2) and (3) Crown, Alan David and Lucy Davey, eds. Essays in Honour of G.D. Sixdenier: New Samaritan Studies of the Société d'Études Samaritaines. Vols. III and IV: Proceedings of the Congresses of Oxford 1990, Yarnton Manor, and Paris 1992, Collège de France: with Lectures given at Hong Kong 1993 as Participation in the ICANAS Congress. University of Sydney Studies in Judaica 5. [Sydney]: Mandelbaum Publishing, 1995

(4) Morabito, Vittorio, Alan D. Crown, and Lucy Davey, eds. Samaritan Researches Volume $V$ : Proceedings of the Congress of the SES (Milan July 8-12, 1996) and of the Special Section of the ICANAS Congress (Budapest July 7-11 1997). University of Sydney Studies in Judaica 10. [Sydney]: Mandelbaum Publishing, 2000

(5) Shehadeh, Haseeb and Habib Tawa, eds., with the collaboration of Reinhard Pummer. Proceedings of the Fifth International Congress of the Société d'Études Samaritaines, Helsinki, August 1-4, 2000: Studies in Memory of Ferdinand Dexinger. Paris: Librairie Orientaliste Paul Geuthner, 2005

(6) Mor, Menachem and Friedrich V. Reiterer, eds., in collaboration with Waltraud Winkler. Samaritans: Past and Present: Current Studies. Studia Judaica 53; Studia Samaritana 5. Berlin; New York: De Gruyter, 2010 
(Includes the papers presented at the Samaritan Study Sessions at the International Meeting of the Society of Biblical Literature in Vienna, Austria, July 22-26, 2007)

(7) Zsengellér, József, ed. Samaria, Samarians, Samaritans: Studies on Bible, History and Linguistics. Studia Judaica 66; Studia Samaritana 6. Berlin; Boston: De Gruyter, 2011

(8) Schorch, Stefan, ed. Samaritan Languages, Texts, and Traditions. Studia Judaica 75; Studia Samaritana 8. Berlin: De Gruyter, 2021

(9) Dusšek, Jan, ed. The Samaritans in Historical, Cultural and Linguistic Perspectives. Studia Judaica 119; Studia Samaritana 11. Berlin: De Gruyter, 2018

\section{Notes}

(1972, p. 141, my emphasis). In 1907, in his book The Samaritans, Montgomery (1907) dedicated his first chapter to an account of the "Re-Discovery of the Samaritans" in the late sixteenth century after the "dense darkness" of the Middle Ages. For a discussion see (Pummer 2010).

Not Joseph Scaliger as many scholars, following Montgomery (1907, p. 3), believe.

Postel, Linguarum, C II b to C IVb. See (Robert 1988, pp. 16, 18).

Published later by Juynboll (1848).

(Scaliger 1598, Book VII); on Scaliger and the Samaritans see (Robert 1988, pp. 18-22).

See (Adler 1907, p. 21).

As recounted in (Robert 1988, p. 20).

9 For the correspondence in the sixteenth and seventeenth centuries see (Delcor 1988). For the twentieth century see (Steindler Moscati 2000). (Le Jay 1645). On Jean Morin see (Auvray 1959).

Their works are listed in Crown and Pummer (2005).

(Cowley 1909). Selected prayers and hymns were published and translated into modern Hebrew by Ben-Hayyim (1967).

(Juynboll 1848). The edition is based on a manuscript which Scaliger obtained from the Samaritans in Cairo in 1584 (see above). An English translation was published in 1890 by Crane (1890), Chronicle.

See (Grimm 1854).

Golding (1928), calls his chapter on the Samaritans (pp. 126-36): “The Samaritan Doom”.

See, e.g., the title of the book by Callebaut (1990), Les derniers Samaritains. Russell's (2014) book, Heirs to Forgotten Kingdoms, counts the Samaritans among "Disappearing Religions of the Middle East".

(Grimm 1854, p. 6) (transl.: an image of violent death convulsions, an utterly powerless reaction of the last remnants of life which today turned into the death slumber of a painless daze).

(Grimm 1854, p. 196) (transl.: In this way the Samaritans vegetate towards their final extinction).

See the new critical edition of the Pentateuch that is being published under the direction of Schorch. So far, Genesis and Leviticus have appeared: The Samaritan Pentateuch: Volume 1: Genesis (Schorch 2021) and The Samaritan Pentateuch: Volume 3: Leviticus (Schorch 2018). Furthermore, see Tal (2019), Tibåt Mårqe, with Tal's introduction to his new edition and translation in this issue of Religions “Tibåt Mårqe: A New Edition with English Translation”; Lieber (forthcoming), Classical Samaritan Poetry in Context.

For the English translation see (Stenhouse 1985). The edition, “Kitāb", is Stenhouse's (1980) Ph.D. dissertation and is available as a microfilm. A continuation of the Chronicle was published by Levy-Rubin (2002) under the title The Continuatio of the Samaritan Chronicle of Abū l-Fath.

Among the recent publications are above all (Dušek 2007, 2020).

The publications dealing with the impact of the Dead Sea Scrolls findings on the study of the Samaritan Pentateuch are too numerous to be listed here. Suffice it to refer to two of the most recent collective works, viz. Kartveit and Knoppers (2018), and Langlois (2019).

The most important archaeological finds are due to the work of Yitzhak Magen. Among his many publications see (Stern and Magen 2002; Magen 2007, 2008b; Magen et al. 2004; Magen 2008a, 2009, 2019). On Josephus and the Samaritans see (Pummer 2009).

See above all (Ireton 2003; Schreiber 2014; Urien-Lefranc 2019, 2020; Droeber 2013, 2018, 2020). Physical anthropology, especially genetics, was the subject of numerous articles and monographs, primarily from the early to the late twentieth and the early twenty-first century. The main author in this field is and was Batsheva Bonné. For a recent article, see (Bonné-Tamir et al. 
2003). For the publications up to the year 2005, see the entries "Anthropology" and "Genetics" in the Subject Index of Crown and Pummer (2005). Genetics is also the subject of the article by Oefner et al. (2013).

The website of SES is www.socsam.org. For the congresses and their published proceedings, see the Appendix A below.

Various theories have recently been discussed in Kartveit (2019b).

(Hensel 2020b, p. 9). The new perspective on the early tensions between Judah and Samaria was developed especially, but not only, by Hensel and Heckl in a number of publications. For Hensel, see above all Juda and Samaria (Hensel 2016); "On the Relationship" (Hensel 2019); “Ezra-Nehemiah and Chronicles" (Hensel 2020a), and most recently the above mentioned "Yahwistic Diversity" (Hensel 2018a); "Cult Centralization in the Persian Period" (Hensel 2018a) and "Debating Temple" (Hensel 2021). For Heckl, see his book Neuanfang (Heckl 2016), published in the same year as Hensel's book Juda and Samaria; and his article "The Composition of Ezra-Nehemiah" (Heckl 2018). See also the contributions in the collective work Yahwistic Diversity (Hensel et al. 2020).

See the discussion in (Pummer Forthcoming; Bourgel 2019).

See Pummer (2009).

(Pummer Forthcoming).

For the difference between the Jewish and Samaritan canon see (Hjelm 2020); see also (Kartveit 2020, 2019a; Tov 2019).

(Hensel 2020b, p. 24, italics in original). See also most recently (Hensel 2021).

(Knoppers 2013, p. 188). See also (Hensel 2020b, p. 25). Heckl, too, emphasizes that "the Pentateuch was composed as a foundational document for every Israelite of every time" and that "the priesthoods of the two shrines in Palestine [i.e., the temples on Mt. Gerizim and in Jerusalem] were collectively involved in its composition and introduction" (Heckl 2020, p. 137). See also (Bergsma 2019).

See, e.g., (Heckl 2020, p. 137; Houston 2014).

Underlined by Knoppers (2013, p. 189).

(Hensel 2018a; Römer 2018; Hensel et al. 2020). On the centralization formula see (Kartveit 2015).

(Hensel 2018b); Hensel analyses 2 Kings 17, 24-41 and 2 Chr 13 as examples for encoded mentions of the sanctuary on Mt. Gerizim. See also (Hensel 2018a; Römer 2018; Hjelm 1999; Gallagher 2014).

(Alt 1934).

(Heckl 2020, p. 137).

See Hensel's neologism in his chapter heading "Pluriformität und Polytemplismus in nach-exilischer Zeit" (Hensel 2016, p. 208).

(Magen 2008a, p. 149).

(Magen 2008a, p. 98).

In 2016, the city had a population of ca. 214.903; ca. 700 individuals were Christians in 2014, and presently ca. 440 individuals are Samaritans.

\section{References}

Adler, Marcus Nathan. 1907. The Itinerary of Benjamin of Tudela. London: Henry Frowde.

Alt, Albrecht. 1934. Die Rolle Samarias bei der Entstehung des Judentums. In Festschrift Otto Procksch zum sechzigsten Geburtstag am 9 August 1943. Edited by Albrecht Alt, Friedrich Baumgärtel, Walter Eichrodt, Johann Herrmann, Martin Noth, Gerhard von Rad, Ludwig Rost and Ernst Sellin. Leipzig: A. Deichert'sche Verlagsbuchhandlung, pp. 5-28.

Auvray, Paul. 1959. Jean Morin (1591-1659). Revue biblique 66: 397-414.

Ben-Hayyim, Ze'ev. 1967. The Literary and Oral Tradition of Hebrew and Aramaic Amongst the Samaritans, III,2: The Recitation of Prayers and Hymns. Jerusalem: Academy of the Hebrew Language. (In Hebrew)

Bergsma, John S. 2019. A 'Samaritan' Pentateuch? The Implications of the Pro-Northern Tendency of the Common Pentateuch. In Paradigm Change in Pentateuchal Research. Edited by Matthias Armgardt, Benjamin Kilchör and Markus Zehnder. Beihefte zur Zeitschrift für altorientalische und biblische Rechtsgeschichte 22. Wiesbaden: Harrassowitz, pp. 287-300.

Bonné-Tamir, Batsheva, Michael Korostishevsky, Alan J. Redd, Yehuda Pel-Or, Manuel E. Kaplan, and Michael F. Hammer. 2003. Maternal and Paternal Lineages of the Samaritan Isolate: Mutation Rates and Time to Most Recent Common Male Ancestor. Annals of Human Genetics 67: 153-64. [CrossRef] [PubMed]

Bourgel, Jonathan. 2019. The Samaritans during the Hasmonean Period: The Affirmation of a Discrete Identity? Religions 10: 628. [CrossRef]

Callebaut, Paul-Jacques. 1990. Les derniers Samaritains. Collection: Mémoire des Hommes, Paris: ASFAR.

Cowley, Arthur E. 1909. The Samaritan Liturgy. Oxford: Clarendon, 2 vols.

Crane, Oliver Turnbull. 1890. The Samaritan Chronicle or the Book of Joshua, the Son of Nun. Translated from the Arabic with Notes. New York: John B. Alden. 
Crown, Alan D., and Reinhard Pummer. 2005. A Bibliography of the Samaritans: Third Edition: Revised, Expanded, and Annotated. ATLA Bibliography 51. Lanham, Toronto and Oxford: Scarecrow.

Delcor, Mathias. 1988. La correspondance des savants européens, en quête de manuscrits, avec les Samaritains du XVIe au XIXe siècle. In Études samaritaines. Pentateuque et Targum, exégèse et philologie, chroniques. Communications présentées à la table ronde internationale "Les Manuscrits Samaritains. Problèmes et méthodes" (Paris 7-9 octobre 1985). Edited by Jean-Pierre Rothschild and Guy Dominique Sixdenier. Louvain and Paris: E. Peeters, pp. 27-43.

Droeber, Julia. 2013. The Dynamics of Coexistence in the Middle East: Negotiating Boundaries between Christians, Muslims, Jews and Samaritans. Library of Modern Middle East Studies 135. London and New York: I.B. Tauris.

Droeber, Julia. 2018. Does Religious Diversity Work? Samaritans and Their Religious 'Others' in Contemporary Nablus. In The Samaritans in Historical, Cultural and Linguistic Perspectives. Edited by Jan Dušek. Studia Judaica 110; Studia Samaritana 11. Berlin: De Gruyter, pp. 245-66.

Droeber, Julia. 2020. Avoidance as Inter-Religious Competence? Samaritans and Their Religious 'Others' in Nablus, Palestine. Religions 11: 71. [CrossRef]

Dušek, Jan. 2007. Les manuscrits araméens du Wadi Daliyeh et la Samarie vers 450-332 av. J.-C. Culture and History of the Ancient Near East 30. Leiden and Boston: Brill.

Dušek, Jan. 2020. The Importance of the Wadi Daliyeh Manuscripts for the History of Samaria and the Samaritans. Religions 11: 63. [CrossRef]

Gallagher, Edmond L. 2014. Cult Centralization in the Samaritan Pentateuch and the Origins of Deuteronomy. Vetus Testamentum 64: 561-72. [CrossRef]

Golding, Louis. 1928. Those Ancient Lands: Being a Journey to Palestine. New York: Alfred A. Knopf.

Grimm, Joseph. 1854. Die Samariter und ihre Stellung in der Weltgeschichte. (Mit besonderer Rücksicht auf Simon den Magier). Ein Beitrag zur Kirchengeschichte. München: J.G. Weiß.

Heckl, Raik. 2016. Neuanfang und Kontinuität in Jerusalem. Forschungen zum Alten Testament 104. Tübingen: Mohr Siebeck.

Heckl, Raik. 2018. The Composition of Ezra-Nehemiah as a Testimony for the Competition Between the Temples in Jerusalem and on Mt. Gerizim in the Early Years of the Seleucid Rule Over Judah. In The Bible, Qumran, and the Samaritans. Edited by Magnar Kartveit and Gary N. Knoppers. Studia Judaica 104; Studia Samaritana 10. Berlin and Boston: De Gruyter, pp. 115-32.

Heckl, Raik. 2020. The Temple within the Book and Its Function: Considerations on the Cultic Concept of the Composition of the Torah. In Yahwistic Diversity and the Hebrew Bible: Tracing Perspectives of Group Identity from Judah, Samaria, and the Diaspora in Biblical Traditions. Edited by Benedikt Hensel, Dany Nocquet and Bartosz Adamczewski. Forschungen zum Alten Testament, 2. Reihe, 120. Tübingen: Mohr Siebeck, pp. 135-50.

Hensel, Benedikt, Dany Nocquet, and Bartosz Adamczewski, eds. 2020. Yahwistic Diversity and the Hebrew Bible: Tracing Perspectives of Group Identity from Judah, Samaria, and the Diaspora in Biblical Traditions. Forschungen zum Alten Testament II 120. Tübingen: Mohr Siebeck.

Hensel, Benedikt. 2016. Juda und Samaria. Zum Verhältnis zweier nach-exilischer Jahwismen. Forschungen zum Alten Testament 110. Tübingen: Mohr Siebeck.

Hensel, Benedikt. 2018a. Cult Centralization in the Persian Period: Biblical and Historical Perspectives. Semitica 60: 221-72.

Hensel, Benedikt. 2018b. Das JHWH-Heiligtum am Garizim: Ein archäologischer Befund und seine literar- und theologiegeschichtliche Einordnung. Vetus Testamentum 68: 73-93. [CrossRef]

Hensel, Benedikt. 2019. On the Relationship of Judah and Samaria in Post-Exilic Times: A Farewell to the Conflict Paradigm. Journal for the Study of the Old Testament 44: 19-42. [CrossRef]

Hensel, Benedikt. 2020a. Ezra-Nehemiah and Chronicles-New Insights into the Early History of Samari(t)an-Jewish Relations. Religions 11: 98. [CrossRef]

Hensel, Benedikt. 2020b. Yahwistic Diversity and the Hebrew Bible: State of the Field, Desiderata, and Research Perspectives in a Necessary Debate on the Formative Period of Judaism(s). In Yahwistic Diversity and the Hebrew Bible: Tracing Perspectives of Group Identity from Judah, Samaria, and the Diaspora in Biblical Traditions. Edited by Benedikt Hensel, Dany Nocquet and Bartosz Adamczewski. Tübingen: Mohr Siebeck, pp. 1-44.

Hensel, Benedikt. 2021. Debating Temple and Torah in the Second Temple Period: Theological and Political Aspects of the Final Redaction(s) of the Pentateuch. In Torah, Temple, Land. Construction of Judaism in Antiquity. Edited by Markus Witte, Jens Schröter and Verena Lepper. Texts and Studies in Ancient Judaism 184. Tübingen: Mohr Siebeck, pp. 27-47.

Hjelm, Ingrid. 1999. Cult Centralization as a Device of Cult Control? Scandinavian Journal of the Old Testament 13: 298-309. [CrossRef] Hjelm, Ingrid. 2020. The Samaritan and Jewish Versions of the Pentateuch: A Survey. Religions 11: 85. [CrossRef]

Houston, Walter. 2014. Between Salem and Mount Gerizim: The Context of the Formation of the Torah Reconsidered. Journal of Ancient Judaism 5: 311-34. [CrossRef]

Ireton, Sean. 2003. The Samaritans: Strategies for Survival of an Ethno-Religious Minority in the Twenty-First Century. Master's thesis, University of Kent at Canterbury, Department of Anthropology, Canterbury, UK.

Juynboll, Th. Guil. Joh. 1848. Chronicon Samaritanum, Arabice conscriptum, cui titulus est Liber Josuae. Ex unico codice Scaligeri nunc primum edidit, Latine convertit, annotatione instruxit, et dissertationem de codice, de chronico, et de quaestionibus, quae hoc libro illustrantur, praemisit Th. Guil. Juynboll. Lugduni Batavorum: S. \& J. Luchtmans. 
Kartveit, Magnar, and Gary N. Knoppers, eds. 2018. The Bible, Qumran, and the Samaritans. Studia Judaica 104; Studia Samaritana 10. Berlin and Boston: De Gruyter.

Kartveit, Magnar. 2015. The Place That the Lord Your God Will Choose. Hebrew Bible and Ancient Israel 4: 205-18. [CrossRef]

Kartveit, Magnar. 2019a. Scholars' Assessments of the Relationship between the Pre-Samaritan Texts and the Samaritan Pentateuch. In The Samaritan Pentateuch and the Dead Sea Scrolls. Edited by Michael Langlois. Contributions to Biblical Exegesis and Theology 94. Leuven, Paris and Bristol: Peeters, pp. 1-17.

Kartveit, Magnar. 2019b. Theories of the Origin of the Samaritans-Then and Now. Religions 10: 661. [CrossRef]

Kartveit, Magnar. 2020. The Tension between the Law and the Prophets as a Background to the Formation of the Samaritan Pentateuch. In Yahwistic Diversity and the Hebrew Bible: Tracing Perspectives of Group Identity from Judah, Samaria, and the Diaspora in Biblical Traditions. Edited by Benedikt Hensel, Dany Nocquet and Bartosz Adamczewski. Forschungen zum Alten Testamentt, 2. Reihe, 120. Tübinben: Mohr Siebeck, pp. 263-82.

Knoppers, Gary N. 2013. Jews and Samaritans: The Origins and History of Their Early Relations. New York: Oxford University Press.

Langlois, Michael, ed. 2019. The Samaritan Pentateuch and the Dead Sea Scrolls. Contributions to Biblical Exegesis \& Theology 94. Leuven: Peeters.

Le Jay, Guy-Michel, ed. 1645. Biblia Hebraica, Samaritana, Chaldaica, Graeca, Syriaca, Latina, Arabica, quibus textus originales totius Scripturae Sacrae, quorum pars in editione Complutensi deinde in Antuerpiensi regiis sumptibus extat, nunc integri, ex manuscriptis toto ferè orbe quaesitis exemplaribus, exhibentur. Lutetiae Parisiorum: Excudebat Antonius Vitré, Regis, Reginae Regentis, \& Cleri Gallicani typographus, 9 vols. in 10.

Levy-Rubin, Milka. 2002. The Continuatio of the Samaritan Chronicle of Abū l-Fath al-Sāmirī al-Danafí. Studies in Late Antiquity and Early Islam 10. Princeton: Darwin Press.

Lieber, Laura S. forthcoming. Classical Samaritan Poetry in Context. University Park: Penn State University Press.

Macdonald, John. 1972. The Discovery of Samaritan Religion. Religion 2: 141-53. [CrossRef]

Magen, Yitzhak, Haggai Misgav, and Levana Tsfania. 2004. Mount Gerizim Excavations. Volume I: The Aramaic, Hebrew and Samaritan Inscriptions. Judea \& Samaria Publications 2. Jerusalem: Staff Officer of Archaeology-Civil Administration of Judea and Samaria, Israel Antiquities Authority.

Magen, Yitzhak. 2007. The Dating of the First Phase of the Samaritan Temple on Mount Gerizim in Light of the Archaeological Evidence. In Judah and the Judeans in the Fourth Century B.C.E.. Edited by Oded Lipschits, Gary N. Knoppers and Rainer Albertz. Winona Lake: Eisenbrauns, pp. 157-211.

Magen, Yitzhak. 2008a. Mount Gerizim Excavations. Volume II: A Temple City. Judea \& Samaria Publications 8. Jerusalem: Staff Officer of Archaeology - Civil Administration of Judea and Samaria, Israel Antiquities Authority.

Magen, Yitzhak. 2008b. Samaritan Synagogues. In The Samaritans and the Good Samaritan. Edited by Yitzhak Magen. Judea and Samaria Publications 7. Jerusalem: Staff Officer of Archaeology-Civil Administration of Judea and Samaria, pp. 117-80, Israel Antiquities Authority.

Magen, Yitzhak. 2009. Flavia Neapolis: Shechem in the Roman Period. Judea \& Samaria Publications 11. Jerusalem: Staff Officer of Archaeology-Civil Administration of Judea and Samaria, Israel Antiquities Authority. vol. 1.

Magen, Yitzhak. 2019. Flavia Neapolis: Shechem in the Roman Period. Judea \& Samaria Publications 11. Jerusalem: Staff Officer of Archaeology-Civil Administration of Judea and Samaria, Israel Antiquities Authority. vol. 2.

Mawer, John. 1737. Roma Meretrix: Or, an Enquiry Whether the Predicted Apostacy of the Roman Church Have Not the Nature of a Divorce from Christ; and Whether, Upon Its Final Excision, We May Not Expect the Restoration of the Jews with the Fulness of the Gentiles. With a Prefatory Discourse, Address'd to His Grace, the Lord Archbishop of Canterbury, Wherein Is Occasionally Asserted the Usefulness and Antiquity of the Samaritan Pentateuch, Which with the Samaritan Version Is Intended to Accompany the Hebrew Text, with the Greek and Ethiopic Versions, Ec. in a New Edition of the Original Scriptures, Whereof a large Specimen Is Prepared for the Press. Newcastle upon Tyne: John White.

Montgomery, James Alan. 1907. The Samaritans: The Earliest Jewish Sect. Their History, Theology and Literature. Philadelphia: The J.C. Winston Co.

Oefner, Peter J., Georg Hölzl, Peidong Shen, Isaac Shpirer, Dov Gefel, Tal Lavi, Eilon Woolf, Jonathan Cohen, Cengiz Cinnioglu, Peter A. Underhill, and et al. 2013. Genetics and the History of the Samaritans: Y-Chromosomal Microsatellites and Genetic Affinity between Samaritans and Cohanim. Human Biology 85: 825-57. [CrossRef] [PubMed]

Postel, Guillaume. 1538. Linguarum duodecim characteribus differentium alphabetum, introductio, ac legendi modus longè facilimus. Linguarum nomina sequens proximè pagella offeret. Prostant Parisiis: Apud Dionysium Lescuier.

Pummer, Reinhard. 2009. The Samaritans in Flavius Josephus. Texts and Studies in Ancient Judaism 129. Tübingen: Mohr Siebeck.

Pummer, Reinhard. 2010. Samaritanism - A Jewish Sect or an Independent Form of Yahwism? In Samaritans: Past and Present: Current Studies. Edited by Menachem Mor and Friedrich V. Reiterer. Studia Judaica 53; Studia Samaritana 5. Berlin and New York: De Gruyter, pp. 1-24.

Pummer, Reinhard. Forthcoming. Samaritans and Jews in Late Antiquity: Selected Case Studies. In Gary N. Knoppers Memorial Volume. Tübingen: Mohr Siebeck. 
Robert, Philippe de. 1988. La naissance des études samaritaines en Europe aux XVIe et XVIIe siècles. In Études samaritaines: Pentateuque et Targum, exégèse et philologie, chroniques. Communications présentées à la table ronde internationale "Les manuscrits samaritains. Problèmes et méthodes" (Paris 7-9 Octobrer 1985). Edited by Jean-Pierre Rothschild and Guy Dominique Sixdenier. Louvain and Paris: E. Peeters, pp. 15-26.

Römer, Thomas. 2018. Cult Centralization and the Publication of the Torah Between Jerusalem and Samaria. In The Bible, Qumran, and the Samaritans. Edited by Magnar Kartveit and Gary N. Knoppers. Studia Judaica 104; Studia Samaritana 10. Berlin and Boston: De Gruyter, pp. 79-92.

Russell, Gerard. 2014. Heirs to Forgotten Kingdoms: Journeys into the Disappearing Religions of the Middle East. New York: Basic Books.

Scaliger, Joseph Justus. 1598. Opus de emendatione temporum, castigatius et auctius... Item veterum Graecorum fragmenta selecta... cum notis ejusdem Scaligeri. Lugduni Batavorum: Ex Officina plantiniana F. Raphelengii.

Schorch, Stefan, ed. 2018. The Samaritan Pentateuch: A Critical Editio Maior. Volume 3: Leviticus. Berlin and Boston: De Gruyter.

Schorch, Stefan, ed. 2021. The Samaritan Pentateuch: A Critical Editio Maior. Volume 1: Genesis. Berlin and Boston: De Gruyter.

Schreiber, Monika. 2014. The Comfort of Kin: Samaritan Community, Kinship, and Marriage. Brill's Series in Jewish Studies 51; Leiden and Boston: Brill.

Steindler Moscati, Gabriella. 2000. The Correspondence Between the Samaritans and Yizhaq Ben-Zvi: New Evidence about Their Cultural and Political Relationship. In Samaritan Researches. Volume V. Edited by Vittorio Morabito, Alan Crown and Lucy Davey. Studies in Judaica 10. Sydney: Mandelbaum Publishing, pp. 3.64-74.

Stenhouse, Paul. 1980. The Kitāb al-Tarīkh of Abu 'l-Fath: A New Edition with Notes. Ph.D. dissertation, University of Sydney, Sydney, Australia.

Stenhouse, Paul. 1985. The Kitāb al-Tarìkh of Abū 'l-Fath: Translated into English with Notes. Studies in Judaica 1. Sydney: Mandelbaum Trust, University of Sydney.

Stern, Ephraim, and Yitzhak Magen. 2002. Archaeological Evidence for the First Stage of the Samaritan Temple on Mount Gerizim. Israel Exploration Journal 52: 49-57.

Tal, Abraham, ed. 2019. Tibåt Mårqe: The Ark of Marqe: Edition, Translation, Commentary. Studia Judaica 92; Studia Samaritana 9. Berlin and Boston: De Gruyter.

Tov, Emanuel. 2019. From Popular Jewish LXX-SP Texts to Separate Sectarian Texts: Insights from the Dead Sea Scrolls. In The Samaritan Pentateuch and the Dead Sea Scrolls. Edited by Michael Langlois. Contributions to Biblical Exegesis and Theology 94. Leuven, Paris and Bristol: Peeters, pp. 19-40.

Urien-Lefranc, Fanny. 2019. Au croisement des regards. Ancrage territorial, mobilités et négociations identitaires. Le cas des Samaritains de Holon (Israël) et de Kiryat Lûzah (Palestine). Ph.D. dissertation, École des Hautes Études en Sciences Sociales (EHESS), Paris.

Urien-Lefranc, Fanny. 2020. From Religious to Cultural and Back Again: Tourism Development, Heritage Revitalization, and Religious Transnationalizations among the Samaritans. Religions 11: 86. [CrossRef] 